\title{
An Exploratory Study on the use of Social Networks in Building Customer Relationships
}

\author{
Estudo Exploratório sobre o uso das Redes Sociais na Construção do \\ Relacionamento com Clientes
}

Estudio Exploratorio sobre el uso de las Redes Sociales en la Relación con el Cliente

\author{
Thelma Valéria Rocha ${ }^{1}$ \\ Caroline Louise Stedefeldt Jansen ${ }^{2}$ \\ Eduardo Lofti ${ }^{3}$ \\ Rodrigo Ribeiro Fraga ${ }^{4}$
}

Received on May 2, 2011 / Approved on April 25, 2013.

Responsible Editor: João Maurício Gama Boaventura, Dr.

Evaluation process: Double Blind Review

\begin{abstract}
This study analyzes how large Brazilian companies use social networks to build customer relationships. Our theoretical references include: social networks and sociabilities; the social networks Twitter, Facebook and Orkut; and relationship marketing. Empirically, we carried out a multiple, qualitative case study in three different companies belonging to different sectors: Company A (Health and Beauty), Company B (Technology), and Company C (Publishing). Eight semi-structured in-depth interviews were carried out between April and September 2010. As a result, we observed that the referred companies are using social networks as a
\end{abstract}

channel to offer clients information and services. Organizational structures vary in name and format. At the Health Care company, the Public Relations department is responsible and hires an external Public Relations Agency to take care of social networks. At the Technology company, the responsible department is called Online Media Management, and also deals with social networks through an external Communications Agency. At the Publishing House, strategy and implementation are carried out internally, by journalists, but with little interaction with the two departments (Database Marketing and Signatures) responsible for customer relationships.

1. Doctor in Business Administration by the University of São Paulo’s (USP) Faculty of Economics, Management and Accounting

Professor at the Higher School of Advertising and Marketing (ESPM) [tvrocha@espm.br].

2. Graduated in Business Administration by the Higher School of Advertising and Marketing (ESPM) [jansen.carol@gmail.com].

3. Graduated in Business Administration by the Higher School of Advertising and Marketing (ESPM) [eduardolofti@gmail.com].

4. Graduated in Business Administration by the Higher School of Advertising and Marketing (ESPM) [rodofraga@gmail.com]. Authors' address: Rua Dr. Álvaro Alvim, 123 - Vila Mariana, São Paulo - SP - CEP 04018-010- Brazil 
We conclude that there are opportunities for improving online services in all three companies, through implementation of custom actions. This study innovates by exploring the use of social networks and relationship marketing, and discusses the structures through which they are being implemented in Brazil.

Keywords: Marketing strategy. Social networks. Relationship marketing.

\section{RESUMO}

Este estudo investiga a utilização das redes sociais na construção do relacionamento com clientes em empresas de grande porte no Brasil. O referencial teórico inclui: redes e sociabilidades virtuais; as redes sociais: Twitter, Facebook e Orkut; e marketing de relacionamento. Na parte empírica, de natureza qualitativa, foi realizado um estudo de caso múltiplo em três grandes empresas de diferentes setores denominadas Empresa A (Higiene e Beleza), Empresa B (Tecnologia) e Empresa C (Editorial). Ao todo, foram feitas oito entrevistas em profundidade com gestores das áreas envolvidas, no período entre abril e setembro de 2010. Como resultados, percebe-se que as empresas em questão estão utilizando as redes sociais como um canal para oferecer conteúdo e prestação de serviços aos clientes. As estruturas organizacionais variam de nome e formato. No caso da empresa de Higiene e Beleza, a área de Relações Públicas é responsável e terceiriza a implementação em uma Agência de Relaçóes Públicas externa. $\mathrm{Na}$ empresa de Tecnologia, a área responsável é denominada Gestão de Mídia On-line, e também executa a implementação por meio de uma Agência de Comunicação externa. Na Editora, a estratégia e a execução são feitas internamente, por jornalistas, mas com pouca interação com as duas gerências (Database Marketing e Assinaturas) responsáveis pelo relacionamento com os clientes. Como conclusão, em todas as empresas existem oportunidades de aprimoramento dos serviços on-line, pela implementação de ações personalizadas. Como contribuiçóes, este estudo inova ao explorar o uso das redes sociais frente à teoria de marketing de relacionamento, e discute a estrutura com que estão sendo implementadas no Brasil.

Palavras-chave: Estratégia de marketing. Redes sociais. Marketing de relacionamento.

\section{RESUMEN}

Este estudio analiza cómo las grandes empresas están utilizando las redes sociales para establecer relaciones con sus clientes en Brasil. Con este fin, se presenta una revisión teórica de las redes virtuales y la sociabilidad. Las redes sociales son Twitter, Facebook y Orkut, y el marketing relacional. La parte empírica del trabajo, de tipo cualitativo, se basa en un estudio de casos múltiples en tres grandes empresas de diferentes sectores denominadas: La Empresa A (Salud y Belleza), la Empresa B (Tecnología) y la Empresa C (Editorial). Se realizaron ocho entrevistas en profundidad con los gerentes en el período de abril a septiembre de 2010. Como resultado, es evidente que las empresas estudiadas recurren a las redes sociales como canal para ofrecer contenido y servicios a los clientes. Las estructuras varían en nombre y forma. En el caso de la empresa de Higiene y Belleza, el área de Relaciones Públicas es responsable de la subcontratación de una Agencia de Relaciones Públicas externa. Respecto a la compañía de Tecnología, el área responsable se llama gestión de medios online, y también se ejecuta a través de la aplicación de una Agencia de Comunicación Externa. Respecto a la Editora, la estrategia y la ejecución es realizada internamente por los periodistas, pero con poca interacción con las dos gerencias (Database Marketing y Suscripciones), responsables de las relaciones con los clientes. En conclusión, en todas las empresas existen oportunidades para la mejora de los servicios en línea, por la implementación de acciones personalizadas. Como aportaciones, este estudio abre nuevos caminos para explorar el uso de la teoría social frente a la creación de redes de marketing relacional, y se analiza cómo se está llevando a c abo en Brasil.

Palabras clave: Estrategia de marketing. Redes sociales. Marketing relacional. 


\section{INTRODUCTION}

Social media play a fundamental role in changing the nature of communications within and without organizations. Immersion in Internet-based social media allows people to communicate with hundreds and thousands of others about products and companies (MANGOLD; FAULDS, 2009).

In this environment, companies have been looking for more economical and efficient communication possibilities for their products and services. Harris and Rae (2009) highlight the power of social media in extending corporate communications and generating economical communication options for organizations.

Social media include networks, forums, microblogs, blogs, podcasts and online virtual communication, amongst others. All these channels (microblogs and other networks) enable companies to attract users and build virtual communities, to analyze the actions of customers within those communities, to send special messages geared to the interests of these communities, and to suggest activities that are accepted within them (KURUCZ, 2008).

Organizations are using social media to achieve tangible benefits for their businesses, such as sales increases, site optimization and improvement of customer relationships (HARRIS, RAE, 2009).

Thus, from the organizations' point of view, this study investigates how large companies are using social media, particularly Twitter, Facebook and Orkut social networks, to communicate with customers and, through them, establish relationships.

The problem to be investigated is the following: how do large companies in Sáo Paulo use social networks such as Twitter, Facebook and Orkut in building their customer relationships?

Our goal is to explore how three large companies in São Paulo use these social networks to build customer relationships. In this context, we seek to analyze which social networks are most used by organizations, the criteria behind this choice and its perceived returns.
This topic is contemporary and relevant due to the increasing number of companies which make use of social media in their communication plans. As justifications, social networks have become increasingly important over the last few years and are now used by companies as a marketing tool. In 2010, 79\% of the world's biggest companies were present in social media.

In academia, there is a perceived shortage of articles referring to the topic within the field of Administration. And there is growing interest in the topic amongst companies, so this study aims at bridging the gap by exploring how three large companies use their social networks to build customer relationships.

\section{THEORETICAL REFERENTIAL}

The theoretical referential will give support to empirical research comprises social networks and interactions, the main social networks in Brazil - Twitter, Facebook and Orkut -, and relationship marketing.

\section{I Social networks and interactions}

In this study, we use the social networks concept that has its origins in the Communications field, in which social networks are studied as Computer Mediated Communication. Boyd and Ellison (2007) carried out a seminal study in the area, pointing out the evolution of social networks since their creation, in 1997, with the sixdegrees.com site.

These authors define social networks as a space for exchanges and social interactions. This concept is based on Degenne and Forse (1999), who consider a social network as a set of actors and their connections.

The Computer Mediated Communication differential, according to Boyd and Ellison (2007), is precisely the fact that these new spaces reveal the traces left by social networks, making these groups more noticeable. 
The Internet not only helps new networks to be established but also contributes to the upkeep of social groups that have already been established by actors, thus providing a space for social interaction as a third virtual place (OLDENBURG, 1999).

Thus, the study of social networks on the Internet has brought about a whole new outlook by researchers, particularly with regard to the mode of appropriation of these tools (BOYD, 2004; RECUERO, 2009).

According to Watzlawick, Beavin and Jackson (2000), interaction is the action that takes place between individuals and is always a communication process. These interactions are the social ties that connect actors within the social network (WASSERMAN, FAUST, 1994). Social ties can be strong and weak. The strong ones are those that express intimacy (GRANOVETTER 1973, 1983), which are capable of withstanding frequent exchanges and greater social capital charges. Weak ties, on the other hand, are those that indicate actors who are more socially distant, which harbor fewer interactions and lower social capital charge.

Quan-Haase and Wellman (2002) highlight Computer Mediated Communication's ability to assist in the upkeep of social capital and social ties between the actors involved. The authors consider that social capital is made up of the resources that can be perceived to be exchanged and made within the social network, through the content of interactions.

Accordingly, from the empirical aspect, we will examine forms of social interaction created by analyzed companies within their social networks.

\subsection{The use of social networks}

According to Boyd and Ellison (2007), social networks allow individuals to present themselves to each other, establishing and maintaining relationships. The purpose of their use is in the interaction between people who already know each other or who want to meet new people.

Smith (2009) classifies social networking as a global phenomenon that is spreading around the world and becoming an important marketing tool. Social networks are providing companies with tools to target campaigns according to the profile of their users and communities.

Mangold and Faulds (2009) point out that social media are a hybrid element in the promotional mix, since they allow consumers to speak directly with companies. The content, duration, and frequency of conversations based on social networks occur between customers and outside the control of managers, in contrast to the traditional elements of marketing communication, in which a high degree of control by organizations is present. In addition, managers must learn to participate in customers' discussions and link them to the company's mission and results.

Another element that turns social networks into important marketing tools is the fact that they contain important details about their users, habits, workplaces and preferences, as well as demographic and personal characteristics (COMM 2009).

According to Recuero (2009), there are four core values that permeate the use of social networks by companies:

1. Visibility: Social networking sites allow users to be permanently connected with their brands.

2. Reputation: this is a perception built by other actors, that is, the impression that other people have about a certain individual or company.

3. Popularity: this is directly connected to the audience, which is facilitated in social networks. On the Internet, an audience can be measured by the number of visits to a profile, amongst other elements.

4. Authority: this is the power to influence a user within the social network. It is a measure of the effective influence of a social actor with respect to his network, along with the perception other users have of his reputation.

A key characteristic of social networks is the speed with which information is transmitted; much of this information is divulged like an epidemic, reaching extremely large audiences. 


\subsection{Brazil's main social networks}

This section analyzes Twitter, Facebook and Orkut social networks.

Twitter was founded in 2006 and, according to research carried out by Semiocast in 2012, has 517 million users worldwide - 142 million of them in the United States. In Brazil, it is the second largest social network, with approximately 41.2 million registered users social (TECHCRUNCH, 2012).

The Twitter interface allows any user to read and post messages up to 140 characters. The average Brazilian company posting is 5 per day, and about $11.2 \%$ of the messages that contain trademarks are sent to other users (ORRICO, 2010).

According to Comm (2009), there are two characteristics that differentiate Twitter from other social networks. The first is its simplicity and the other, the sheer volume of users. The author considers Twitter a communication tool that works in two ways: users can communicate what they are doing or throw a question to their contacts, or subject matter experts, who then give their opinion. "Tweets (posted messages) are designed to describe what you are doing at a given moment, but may also include opinions, announcements and conversations" (COMM, 2009, p. 76).

Followers of a company on Twitter may be considered their most devoted customers. They want to collaborate, and a way of rewarding them is to offer insider information on new products and the like. They are the company's main promoters, talking to friends about products and remaining connected with questions, answers and suggestions.

According to Comm (2009), corporate tweets fit into our categories:

1. News about the company: well accepted by followers. However, they must be interesting and somehow affect the reader.

2. Customer support: this means publishing tweets that address problems and suggest solutions.

3. Return: the company can help the customer with problems almost instantly, showing that it is helpful and agile when responding and giving support to those in need of assistance.

4. Special offers: tweets containing exclusive promotions that followers cannot find anywhere else. This ends up encouraging them to read updates, and leads to extra sales.

Facebook, on the other hand, is one of the fastest growing social networks in Brazil. It was created in 2004 by four Harvard students and is a social tool that helps people communicate more efficiently with their friends, colleagues and family, and that nowadays has approximately 955 million active users worldwide (FACEBOOK, 2012); amongst these users, 46.3 million used it in the last three months in Brazil (INDO.POST. COM, 2012).

According to Recuero (2009), Facebook operates through profiles and communities, and is able to create and add extra applications, such as games and tools.

To Boyd and Ellison (2007), the possibility of adding applications is a Facebook differential, allowing users to further customize their pages. It is also seen as one of the most private social networks, because only users who are part of the same network can view each other's profiles (BOYD; ELLISON, 2007).

To Recuero (2009), a social network is defined as a set of two elements: actors (individuals, institutions or groups) and their connections (interactions or social ties).

Building the identity of a social actor can occur through his Facebook profile, to express elements of his personality or individuality. According to Recuero (2009), in cyberspace there is no face-to-face communication - so it is essential that actors input their faces and information that best create individuality and empathy. This requirement is essential for communication to be structured. For the author, connections in social networks are made through social ties, which in turn are made up through social interaction amongst actors.

According to Shih (2009), Facebook is a tool for rapid integration. When a user updates a message, writes on his profile, make a comment or interacts with a brand, his followers find out. This increases returns on stocks. 
Orkut, on the other hand, according to Telles (2006), is a social networking site created in 2004 by the company Google. Its name comes from the name of its creator himself, Orkut Büyükkökten, a Turkish engineer at the company. The site's stated goal is to help its users create new friendships and maintain relationships.

Each Orkut user has an Orkut account linked to an e-mail address. From this account, a profile is created with each member's personal characteristics, such as a physical description, a list of books and music of his choice, a presentation text and photos. Each member's profile is made up of a page with individual comments, in which his network of friends interact through messages called scraps. The site also offers the possibility of creating communities. Each community has an owner, and users that are accepted by this owner become a part of it. Discussion forums can be created within communities (TELLES, 2006).

The Orkut site itself provides some demographic information about its users: $53 \%$ are between 18 and 25 years old. The vast majority is interested in making or maintaining friendships (44\%). Worldwide, Orkut has 66 million users, half of them in Brazil (50\%), followed by India (20\%) and the U.S. (18\%) (ORKUT, 2012).

Chart 1 offers a comparative analysis between Twitter and Facebook.

\begin{tabular}{|c|c|c|c|}
\hline \multirow{2}{*}{ Dimensions } & \multicolumn{3}{|c|}{ Social network } \\
\hline & Twitter & Facebook & Orkut \\
\hline Year created & 2006 & 2004 & 2004 \\
\hline $\begin{array}{l}\text { Number of users } \\
\text { worldwide }\end{array}$ & 517 million $\left(^{*}\right)$ & 955 million $\left({ }^{* *}\right)$ & 66 million $(* * *)$ \\
\hline Number of users in Brazil & $\begin{array}{c}41,2 \text { million registered } \\
\text { users }\end{array}$ & $\begin{array}{l}46,3 \text { million users in the last } \\
\text { three months }\end{array}$ & 33 million users \\
\hline \multicolumn{4}{|l|}{ Characteristics } \\
\hline Objective & $\begin{array}{c}\text { To disseminate } \\
\text { information in a succint } \\
\text { way }\end{array}$ & $\begin{array}{l}\text { Interaction amongst users of } \\
\text { a certain network of contacts }\end{array}$ & $\begin{array}{l}\text { Interaction amongst users of } \\
\text { a certain network of contacts }\end{array}$ \\
\hline Format & Microblog & Profiles/communities & Profiles/communities \\
\hline Presence in Brazil & Average & Strong & Strong \\
\hline Maturity & Average & Average & High \\
\hline Strengths & Simplicity & Privacy and applications & $\begin{array}{c}\text { Active discussion } \\
\text { communities and forums }\end{array}$ \\
\hline Strength as media & Agility in communication & Targeting by niches & Targeting by niches \\
\hline Limitations & Small depth of content & $\begin{array}{l}\text { Difficulty in establishing } \\
\text { discussion groups }\end{array}$ & $\begin{array}{l}\text { Small flexibility for } \\
\text { applications }\end{array}$ \\
\hline
\end{tabular}

CHART 1 - Comparison between social networks

Source: based on sites: Techcrunch (2012), Facebook (c. 2012), Orkut (2012).

In Chart 1 , we observe that the three networks, although recent, include a large number of users. The analyzed networks have different goals and formats.

These formats generate strengths and limitations. In the case of Twitter, the microblogging format (messages up to 140 characters) makes access to profiles easier, contributing to the rapid dissemination of information. This size, however, limits information content.
Facebook, on the other hand, with its profiles format, networks of contacts and communities, ensures the privacy of users and also offers greater customization of profiles through applications. Considered as a social media, it enables public segmentation according the grouping of users.

Orkut is an important social network in Brazil, which harbors $50 \%$ of its users. The format of communities, coupled with this network's high 
level of penetration, enables it to include active discussion forums on various topics, also enabling companies to not only collect spontaneous opinions about their products but also create targeted actions for a specific group of users. As a social media, it also allows for audience segmentation according to the grouping of users.

According to what has been presented, it appears that the use of the mentioned social networks does in fact have potential for companies in building customer relationships.

\subsection{Departments involved in implementing social networks}

From research and information gathered by the Brand Expressions Digital Agency and the Branding and Business Expertise Group North, Blanchard (2010) came up with a presentation in which he points out the departments that are responsible for social media, including activities for planning, implementation and control; they are Marketing, Public Relations, Sales, IT (Information Technology), Customer Services, HR, amongst others.

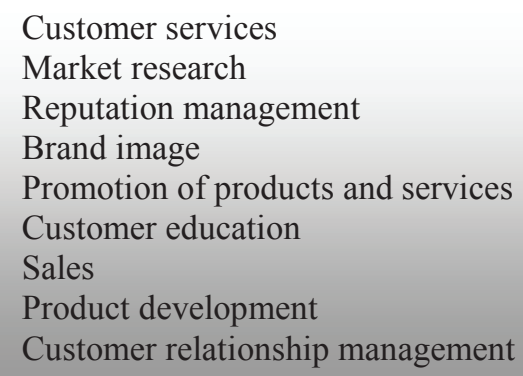

\section{Departments involved}

Activities carried out

FIGURE 1 - Departments involved in social media and activities carried out

Source: Blanchard (2010)

These departments carry out various activities, such as providing customer support; carrying out market research; managing brand reputation; promoting products and services; educating consumers; selling products; developing products; and taking care of the management of customer relationships.

To the author, decisions to implement activities in social networks should consider:

- that results from messages and repercussion cannot be controlled (HARRIS, RAE, 2009). Thus, fear of negative information can appear. But it is better to maintain transparency and to deal with crises than hide and "pretend" that the problem does not exist. This refers to a part of Communications theory that addresses
Crisis Management, highly developed by Public Relations departments;

- that organizations can also monitor markets, competition, and answer customers via social networks. This allows companies to become more proactive about the changing needs of customers, and to come closer to moves by competition.

\subsection{Relationship Marketing and its implementation}

Within Marketing, there is a field focused on studying the relationship with customers called Relationship Marketing. In this area, Levitt (1983) points out the need to manage customer relationships, and stresses that the marketing 
concept includes planning and providing expanded products, keeping in mind all the needs, desires and attitudes of buyers.

Berry (1983), in the context of services marketing, explains that special emphasis should be given to customer retention, to the allocation of resources for keeping them and to strengthening relationships, and not only to trying to attract new customers. Vavra (1993) coined the postmarketing concept, or aftermarketing, so as to build lasting relationships with customers. The author defined relationship marketing as a process of providing continued satisfaction and reinforcement to customer individuals or organizations.

Peppers and Rogers (1994), on the other hand, propose the individual marketing concept, or one-to-one, as a new way of thinking about marketing, no longer geared towards masses, but pointing out the importance of building relationships with each individual client. To McKenna (1993, p. 69): "Relationship marketing is a way of integrating the customer to the company, creating and sustaining the relationship between the company and the customer."

Gummesson (2005) works with three variables: relationships, networks and interaction, applicable to both $\mathrm{B} 2 \mathrm{~B}$ and $\mathrm{B} 2 \mathrm{C}$. The author creates 30 different types of relationships and views the company as a network of interactions.

Thus, one can define relationship marketing as an organizational function and a set of processes, seeking to establish a deep and lasting relationship with customers.

Lindgreen (2001) emphasizes that publications on relationship marketing are usually geared towards implementation rather than towards the cultural and philosophical shift that the topic represents. So as to promote empirical research, the author developed an analytical model, based on extensive literature review, which includes the objectives, instruments and dimensions of relationship marketing, as shown in Figure 2.

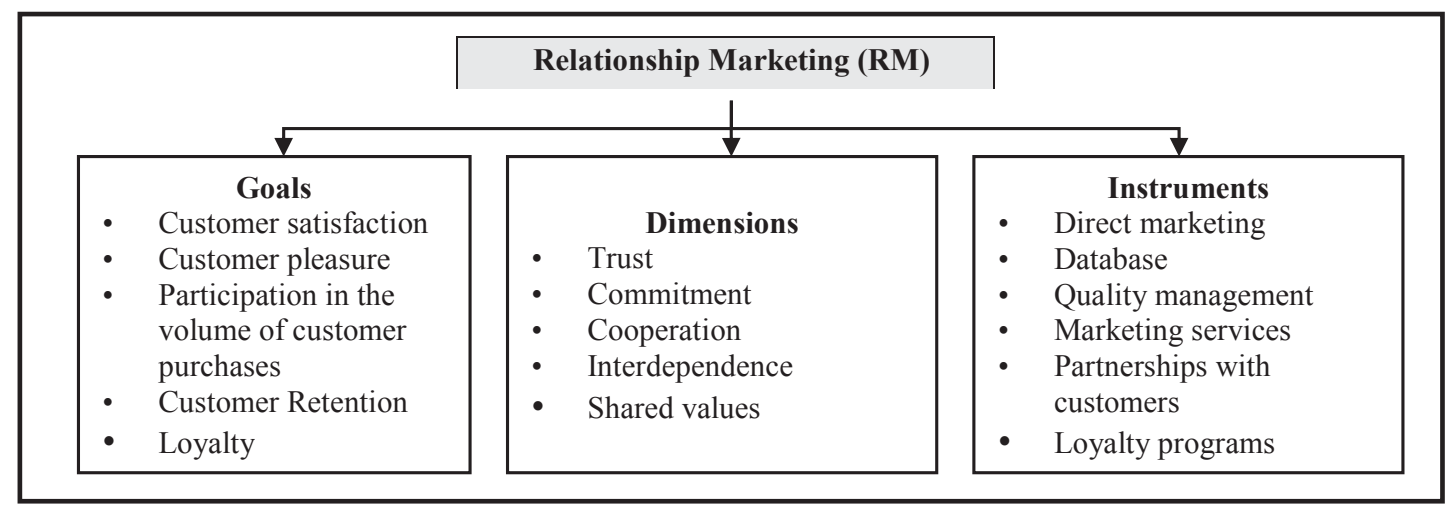

FIGURE 2 - Analytical model of RM goals, dimensions and instruments

Source: adapted from Lindgreen (2001, p.76)

According to Figure 2, RM goals include achieving greater customer satisfaction, increasing customer pleasure, participating in the volume of sales by customers buying the company's products, customer retention and loyalty. The dimensions of interactions between the company and customers, on the other hand, refers to the trust between the parties, commitment, cooperation, interdependence and shared values. The instruments that are used differ and involve direct marketing and database marketing, quality management, marketing services, partnerships with customers and loyalty programs.

Complementing this perspective, Ferreira and Sganzerlla (2000) propose that RM functions are related to the provision of services to customers, to having and using a database, to working on employee engagement, on communication with customers and on loyalty/ retention actions. 
Peppers and Rogers (1994) created oneto-one marketing, or personalized marketing, as a way to gain competitive advantage over competitors through customer differentiation and personalized treatment. To deploy one-to-one marketing, the authors propose an IDIP model in four steps: to identify customers, registering them in a database; to differentiate customers through segmentation by value or use; to interact with customers; and to personalize products and services to certain customers. The steps of the IDIP model are implanted sequentially; that is, first the company identifies its customers, then it sets them apart, to increase interaction and, in some cases, personalize. Personalization is expensive and is usually deployed to only a few clients. Now social networks present themselves as possible channels of interaction between the company and its customers.

To deploy the IDIP model, it is necessary to use technology. According to Gummesson (2005), information technology and the Internet allow for the establishment of networks, allowing for interactions quickly, cheaply and easily. "Technically, electronic relationships are relationships at a distance, which sometimes are translated into a completely new kind of close relationship" (GUMMESSON, 2005, p. 114). Therefore, Information Technology and the Internet play an essential role in the contemporary world.

And the relationships created in the electronic media can forge new patterns of consumption, requiring changes in the way organizations relate to their customers.

\section{METHODOLOGICAL ASPECTS OF EMPIRICAL RESEARCH}

This section seeks to explain the methodological approach employed and the empirical research procedure, so that the study may be reproduced.

\section{I Empirical research description}

To Yin (2005), the choice of research strategy depends on three conditions: a) the type of research question; b) the control the researcher has over actual behavioral events; c) the focus on contemporary phenomena.

Case studies are the preferred strategy when questions arise such as to "how" and "why", when the researcher has little control over events and the focus is placed on real-life phenomena (YIN, 2005).

Yin (2005) distinguishes single-case and multiple-case projects. The single-case study is an appropriate design, when the case is representative, in order to capture the circumstances and conditions under which it occurs. The multiplecase study contains two or more cases in which one makes a similar data collection and analysis of results is presented together.

The decision to carry out a multiple-case study, in this work, is justified by the possibility of developing an exploratory study analyzing the topic based on complex reality, in three companies that operate in a representative way within their different sectors.

\subsection{Empirical research procedures}

Developing the case study followed the protocol suggested by Yin (2005), and a summary of the main elements is presented below:

- goal: To identify how large organizations in Brazil use social networks to build their customer relationships. To this end, we try to analyze which social networks are most used by organizations, the criteria behind this choice, and the return perceived by the company due to this initiative.

- main questions to be answered: "Which are the main social media used by your company and what are the reasons it was chosen?"; "What is the perceived return resulting from presence in the mentioned media?"; "How are the brand and products, amongst others, divulged in social networks?”. Questions and bibliography employed by topics are available in Appendix 1. 
- Criteria for choice of company: large companies (gross operating revenue exceeding US $\$ 300$ million per year) are significantly active in social networks, with accessibility of information by interviewers; from different sectors.

- Methodological aspects: exploratory research using the multiple-case study method (multiple units of analysis).

- Data collection instrument: Before interviews were carried out, we analyzed websites and social networks in which companies operated, in order to understand the company that was going to be studied (its history, products, way of operating, public). Next, eight interviews were carried out with the professionals responsible for the communications and online marketing departments and with the professionals responsible for the companies' accounts in communications agencies referring to social networks.

Chart 2 presents a summary of the topic and the sources of evidence.

\begin{tabular}{|l|l|}
\hline \multicolumn{1}{|c|}{ Topic of questions } & \multicolumn{1}{c|}{ Possible data sources } \\
\hline Company history & Interview, company websites das empresas, news \\
\hline $\begin{array}{l}\text { Goals pursued by actions in social media; perception of their } \\
\text { use; what kind of information they strive to disseminate. }\end{array}$ & Interviews \\
\hline Assessment of results from action in social media & Interviews, documents published by the media \\
\hline Relationship and e-relationship marketing concepts. & $\begin{array}{l}\text { Interviews, documents on actions carried out, documents } \\
\text { planning action }\end{array}$ \\
\hline
\end{tabular}

CHART 2 - Topic of questions to be answered and possible sources of evidence

Source: the authors.

- analysis units: Three large companies from different sectors were selected. The names of the companies were replaced by $\mathrm{A}, \mathrm{B}$ and $\mathrm{C}$, for confidentiality's sake. Company $\mathrm{A}$ is a Health and Beauty Sector multinational company. Company $\mathrm{B}$ is a Technology Sector multinational company; and Company $\mathrm{C}$ is a national publishing house.

At Company A a brand of women's tampons was chosen, since it has a track record in social networks.

At Company B, we analyzed the corporate brand, since its operating strategy in social networks is based on this brand.

At Company $\mathrm{C}$, the publishing house, the architecture magazine nucleus was chosen, due to accessibility and to being a representative case in the use of social networks.

- description of interviews: Eight in-depth interviews, as follows:

- At Company A, two interviews were carried out in São Paulo - the first at the company's office, with the PR manager, responsible for managing social networks for the company's brands, and the second in the Public Relations Agency's office, with the manager responsible for social networks, in April and May 2010.

- at Company B, two interviews were carried out in the São Paulo office, in August 2010 - with the Online Marketing manager, who answers for strategies and campaigns concerning online media, and with the Online Marketing analyst, responsible for monitoring social networks.

- at Company C, four interviews were carried out in two visits to the São Paulo office in September 2010 - on the first visit, three employees from the department were interviewed: the architecture portal's head editor, the Online Marketing analyst, and the journalist responsible for social 
network content; on the second visit, the person responsible for the company's Database Marketing was interviewed.

- data organization: all interviews were recorded and transcribed, and an Excel database was made up with all the information that was collected.

- data analysis: we adapted the content analysis technique proposed by Bardin (2004). On the Excel spreadsheet, questions were grouped into categories, and main components of answers were separated. These spreadsheets were the basis for the drafting of the case, including the Summary Table of answers and inserting phrases by the interviewees.

\section{RESULTS AND DISCUSSION}

In this section we present a concise overview of the cases and discuss results facing theory.

\section{I Case study: Company A}

The Company is a foreign multinational known for its large investments in innovation, which enable several new global brands in the field of Health and Beauty.

Within the company, the marketing and public relations functions are performed by different departments and have different objectives. The Marketing department is focused on managing their marketing mix of brands, aiming to establish them in the market in a sustainable and lasting way.

The Public Relations department, on the other hand, whose manager we interviewed, aims at ensuring that the image of the company and its brands are ensured before society, especially the press and consumers. With regard to relationship marketing, none of the departments aims at implementing relationship marketing programs. Since it is a manufacturer of consumer goods, its consumer base is pulverized and voluminous, and this makes actions for long-term relationships hard to implement, since the company does not have a structured database for this type of initiative. We found that in this case, however, the company carries out Relationship Marketing actions through its social networks.

\section{I.I Social Networks in Company A}

The brand of tampons began operating on the Internet around the year 2000, when a comprehensive website was created with content geared at girls between 12 and 18. The site offers information about the physical changes that occur around the first period in a language that is compatible with its audience.

In Brazil, the site was created in 2006, and, in it, consumers can interact with the company by using the "contact" option. The messages that are sent in by consumers are received by the customer service department, which then answers them according to a script provided by the marketing and public relations departments.

In 2008, the tampon brand hired the PR agency to take care of the site. The agency offers an exclusive, trained team to convey a message corresponding to the language used by the product in social networks.

Furthermore, the message that is taken to social networks must be interesting to users. According to interviewees, this way is the only way it will be disclosed by more and more Internet users.

The content offered must be associated with the message that the brand wishes to communicate, so that the social network user can relate this content with the product. An example of activations on social networks carried out by the brand occurred with nighttime sanitary napkins. For content, information relating to sleep was offered, allowing the user to relate the importance of sleeping well at night with the protection offered by the line of nighttime sanitary napkins.

The PR agency has a department that is dedicated solely to activating social networks; some of its staff works at the company's office, taking care exclusively of its brands. 
The process begins when the Marketing department sends a briefing to the Public Relations department, which is made up of public relations professionals and of staff from the agency that are located within Company A. This area, along with the agency's social network department, come up with a brand activation plan for social networks.

The plan is presented to the Marketing department and, with its approval, the PR department carried out the plan. Every quarter, there is a review of blogs, communities and influencers that will be activated for the campaign, according to the brand's objectives and the returns they offered in past initiatives.

A list of questions and answers to the doubts that arise is provided to the agency that will activate the networks; it contains information about the initiative and the products, as well as about corporate issues.

According to interviewees, there is no one single network that is better than the others in carrying out these actions. Twitter, Facebook and Orkut are all seen as complements to each other.

For the brand of tampons, however, the most appropriate social network is the one made up of bloggers who use Twitter as a tool to divulge their blogs, since they interact with Orkut and Facebook users, and post and publicize videos on YouTube. So, they reach a large number of people in various social networks.

The brand of tampons has two ways of publishing its contents on social networks: firstly, through users and bloggers who are already in the networks (Orkut, Facebook, Twitter and blogs), and secondly, by publishing content to its followers on its Twitter profile brand.

These actions are always aligned with the brand initiative for the quarter, so that the message is in line with the brand's communication in other media.

\subsection{Case study: Company B}

Company $\mathrm{B}$ is a foreign multinational company with origins in the USA, focused on computer manufacturing; it is a leader in innovation within the sector. Its Latin America headquarters are in São Paulo.

Whilst focusing significant efforts on building their brand image on social networks for the B2C market, Company B aims at establishing relationships and strengthening its image to the end consumer.

At Company B, the Online Media manager who was interviewed reports directly to the Marketing director. The Marketing department's main objective is to run campaigns and actions that are in compliance with the planned strategy, geared to both the end consumer market as to the corporate segment, and managing the marketing mix of their brands in a sustainable and lasting way.

The Online Media department aims at taking care of the image of the company and of its product brands before society. It has the support of the press office and of the Communications Agency in seeking to establish strong relationships with key media.

With regard to relationship marketing, none of the departments aims at implementing specific programs of this nature, except for the department that manages Company B's sales channels - that is, the distributors of manufactured products. For this level of relationship, there is a program in which points are accumulated and benefits acquired, according to planning by the sales department. In the case of end consumers, as their base is voluminous, it is hard to implement long-term relationship marketing activities, although it is possible to see that this type of action is present in social networks.

\subsection{Social Networks in Company B in Brazil}

Company B's corporate website in Brazil is a translation of its matrix's site. It is strictly corporate, with information about history, products, jobs and the contact option.

Company B began operating in social networks in Brazil in 2007 when, experimentally, it launched its first corporate blog focused on end consumers who had an interest in technology and business. This blog was developed collaboratively 
by employees, and in it there was no official profile with posting of information.

Currently, Company B operates in various social networks, always through its Communications agency, which is responsible for all the company's actions on social networks in Brazil.

The company operates in social networks Twitter, blogs, Yahoo! Answers, YouTube and Flickr. In blogs, Company B seeks to establish a relationship with bloggers who have some authority in matters concerning technology, providing them always with the latest information on technology and its products.

Yahoo! Answers is a tool from Yahoo in which any Internet user can leave a question that will be answered by other users. Readers of these answers grade their quality.

Company B responds to questions asked by "Computers and Internet" category users, is recognized as a specialist by Yahoo, and can reinforce its brand and advertise its products. The channels that the company has on YouTube and Flickr act as centralizers of all the videos and pictures that are on the Internet. Links are used in their publications, as well as in Twitter - its main active social network.

Within social networks, Company B also seeks to establish relationships with their users by publishing relevant technology information. The company follows all the users that follow it, allowing for an exchange of direct messages; the company receives several questions which are answered by its agency and to each user. Answers are based on a series of standard answers.

Although all doubts and suggestions are answered by Company B, these suggestions are hardly ever taken to the level of product development, since the development cycle and the degree of complexity of technologies involved are high. Suggestions and comments about marketing campaigns, on the other hand, are taken into consideration, because it is possible to solve them within Company B in Brazil, without the need to involve other global instances for their approval.
Campaigns that are created for social networks always use the same profile, so that the company is capable of generating a critical audience over time and can consolidate its contents in a single profile on the network.

\subsection{Case study: Company C}

Company $\mathrm{C}$ is a national leader in the Communications sector. It operates in an integrated way across various different media to provide information, education and entertainment to different segments of the public. Its main products are: editorial content and graphics for magazines, yearbooks, guides, technical publications, marketing, advertising, publicity and the Internet.

In Company $C$, the Marketing department's main objective is to run campaigns and actions aimed at generating demand, both geared to the end consumer market - magazine readers - and to the corporate segment, in order to offer advertising space to advertisers who want to publish something in printed or online content.

The public relations department is organized independently from the Marketing department, and aims at taking care of the corporate image of C Company and of its product brands. Its main function is to ensure that all actions and events that it holds are published in the media.

With regard to relationship marketing, there are two departments aimed at building the customer relationships: Database Marketing (DBM) and Signatures.

\subsection{Social Networks in Company C}

The Architecture nucleus' site was created in December 2005 and consolidates the content of magazines belonging to the field. In this site, the central content is made up of editorials on decoration and construction, updated when new editions of the magazines are published. 
The Architecture nucleus began operating in social networks in Brazil in 2009, on Twitter. The account was created to reflect the site's contents. Before that, however, social networks such as Orkut already had profiles and communities about the Casa nucleus' magazines, all created by fans and readers of these magazines.

Currently, the Architecture nucleus has a fan page on Facebook and a profile on Orkut, both managed by the nucleus itself.

These two pages have similar content to Twitter and also offer the possibility of interacting with users, who can ask questions that will be answered by the reader service group that exists within the Architecture nucleus.

The nucleus has also created an extranet for architects and designers to share experiences; it is also a channel for the sector's market of advertisers to speak directly with these professionals, who are major influencers in their customers's purchases.

To join the network, it is necessary to fill in a registration form and submit it to approval, which is granted by the Architecture nucleus, who checks the accuracy of the information and then approves the professional's entry into the network.

While it is necessary to be a professional in this sector to create a profile in the network, it is open to all Internet users who in it find decorating projects posted by participants, as well as their contacts, in case they want to hire someone to carry out a project.

In social networks, the Architecture nucleus seeks to establish relationships with its users by publishing relevant information on decoration and construction, as well as seeking the views of members on matters referring to decoration and construction. These opinions are often inspiration for creating editorial contents for the website and magazines.
Management of social networking is carried out internally by an Architecture nucleus staff member, who works with those responsible for site marketing. This person answers the questions that customer services did not know how to answer, and plans the schedule of publications and activities in social networks.

\section{COMPARATIVE ANALYSIS OF CASES AND DISCUSSION}

The comparative analysis of cases is separated by topics: social networks and relationship marketing.

\section{I Social networks}

In all cases studied, the marketing department is involved in defining social networks operational strategies. Only in the case of Company A is the Public Relations department also involved in this decision.

The implementation of strategies is performed by outsourced agencies in the case of Company A and Company B, whereas in Company $\mathrm{C}$ it is performed by the Architecture nucleus' Marketing department, which has a journalist to manage social network content.

When creating strategies, the studied companies take into account four elements presented by Recuero (2009) as values that permeate their performances in networks: visibility, reputation, popularity and authority, according to Chart 3. The analyzed companies seek to operate with users who can provide visibility to the brand, measured by the number of people they can impact, and by the credibility they have to endorse content that the brand wants to communicate. 


\begin{tabular}{|l|l|l|l|}
\hline Elements & Company A & Company B & Company C \\
\hline Sector & $\begin{array}{l}\text { Health, beauty and wellness } \\
\text { sector, and cleaning products }\end{array}$ & Technology sector & Communications sector \\
\hline Studied brand & Tampons & Corporate & Architecture \\
\hline Networks used & Twitter and Orkut & Twitter & Twitter, Facebook and Orkut \\
\hline $\begin{array}{l}\text { Responsible } \\
\text { department }\end{array}$ & $\begin{array}{l}\text { - Marketing and Public } \\
\text { Relations: strategy definition } \\
\text { - Public Relations Agency: } \\
\text { strategy implementation }\end{array}$ & $\begin{array}{l}\text { - Marketing: strategy definition } \\
\text { - Communications Agency: } \\
\text { strategy implementation }\end{array}$ & $\begin{array}{l}\text { - Marketing: strategy } \\
\text { definition and implementation }\end{array}$ \\
\hline $\begin{array}{l}\text { Values that } \\
\text { permeate the use } \\
\text { of networks }\end{array}$ & $\begin{array}{l}\text { - Visibility } \\
\text { - Reputation } \\
\text { - Popularity } \\
\text { - Authority }\end{array}$ & $\begin{array}{l}\text { - Visibility } \\
\text { - Reputation } \\
\text { - Popularity } \\
\text { - Authority }\end{array}$ & $\begin{array}{l}\text { - Visibility } \\
\text { - Reputation } \\
\text { - Popularity } \\
\text { - Authority }\end{array}$ \\
\hline
\end{tabular}

CHART 3 - Comparative analysis of social networks used

Source: the authors.

Twitter is used similarly by the three companies, to disseminate news about their brands, answer questions, offer tips and special offers. Another type of action is customer support, observed only in the case of Company $\mathrm{B}$ and Company C; tweets were posted to discuss problems and suggest solutions.
Apart from Twitter, Chart 4 reveals that only Company $\mathrm{C}$ uses Facebook as social network also in order to increase its customer relationships. Company $\mathrm{C}$ has a fan page in which it publishes editorial content and answers any questions from customers; it is also managed by the person responsible for networks in the Architecture nucleus.

\begin{tabular}{|c|c|c|c|}
\hline Elements & Company A & Company B & Company C \\
\hline $\begin{array}{l}\text { Actions in } \\
\text { Twitter }\end{array}$ & $\begin{array}{l}\text { - Company news } \\
\text { - Answers } \\
\text { - Special offers }\end{array}$ & $\begin{array}{l}\text { - Company news } \\
\text { - Customer support } \\
\text { - Answers } \\
\text { - Special offers }\end{array}$ & $\begin{array}{l}\text { - Company news } \\
\text { - Customer support } \\
\text { - Answers } \\
\text { - Special offers }\end{array}$ \\
\hline $\begin{array}{l}\text { Actions in } \\
\text { Facebook }\end{array}$ & Does not use. & Does not use. & $\begin{array}{l}\text { Has a fan page in which it publishes } \\
\text { editorial contents and answers } \\
\text { customer's questions. }\end{array}$ \\
\hline $\begin{array}{l}\text { Actions in } \\
\text { Orkut }\end{array}$ & $\begin{array}{l}\text { Monitoring of communities } \\
\text { and forums that refer } \\
\text { to the topic, spreading } \\
\text { information referring to } \\
\text { the products and answering } \\
\text { questions. }\end{array}$ & Does not use. & $\begin{array}{l}\text { Has a profile in which it publishes } \\
\text { editorial contents and answers } \\
\text { customer's questions. }\end{array}$ \\
\hline $\begin{array}{l}\text { Perspective } \\
\text { on social } \\
\text { networks }\end{array}$ & $\begin{array}{l}\text { - Support from top } \\
\text { executives. } \\
\text { - Considers the continuity } \\
\text { of actions in the network } \\
\text { the strong point. } \\
\text { - Considers always } \\
\text { discussing menstruation a } \\
\text { challenge. }\end{array}$ & $\begin{array}{l}\text { - Locally, top executives offer } \\
\text { certain resistance to actions on } \\
\text { social networks, since there is no } \\
\text { way of measuring their financial } \\
\text { returns. } \\
\text { - Considers its consolidated presence } \\
\text { on Twitter the strong point. } \\
\text { - Considers the non-use of } \\
\text { Facebook e Orkut, and the lack of } \\
\text { involvement of its employees in } \\
\text { the network, as an opportunity. }\end{array}$ & $\begin{array}{l}\text { - Top executives support the use } \\
\text { of social networks, but are not } \\
\text { preoccupied with developing them, } \\
\text { since their financial returns are } \\
\text { inexpressive. } \\
\text { - Considers the easiness to publish } \\
\text { contents the strong point. } \\
\text { - Considers its small team } \\
\text { responsible for actions on networks } \\
\text { an opportunity. }\end{array}$ \\
\hline Return metrics & $\begin{array}{l}\text { Approximate number of } \\
\text { persons impacted. }\end{array}$ & $\begin{array}{l}\text { - Number of views of Twitter } \\
\text { page. } \\
\text { - Number of retweets and answers } \\
\text { to its posts. }\end{array}$ & $\begin{array}{l}\text { - Number of followers or of profile } \\
\text { friends. } \\
\text { - Number of participants in cultura } \\
\text { contests. } \\
\text { - Sales of advertising space. }\end{array}$ \\
\hline
\end{tabular}

CHART 4 - Comparative analysis of social networks

Source: the authors 
As for Orkut, Company A and Company $\mathrm{C}$ are outstanding users. The first monitors communities and forums related to the topic menstruation, in which its publicizes its product initiatives and answers questions.

The same applies to Company C, which besides monitoring and offering support also has its own profile for spreading editorial content. Company B, in turn, does not use Orkut in its actions on social networks.

In the cases studied, the top executives support their companies actions in social networks. Since their returns are difficult to measure, however, there is some resistance on their part to making high investments in networks.

Because of this difficulty in measuring the financial returns of this type of media, companies often measure their actions by the number of people impacted, whereas Company $\mathrm{B}$, as well as the number of impacts, also considers users' responses to their posts. Company $\mathrm{C}$, on the other hand, due to the nature of its activities in publishing editorial content, measures its returns in different ways: on Twitter, by the number of people following and participating in cultural contests and by the selling of advertising space.

Each company considers its strengths in social networks in different ways. Company A considers the continuity of marketing actions in such media; Company B, the consolidated presence of all its divulged contents; and Company $\mathrm{C}$, the ease in publishing information.

They also consider challenges and opportunities differently: to always talk about the topic menstruation, the use of Orkut and Facebook and other social networks, and having more staff to monitor them on a daily basis, applicable to the cases of Company A, Company $\mathrm{B}$ and Company $\mathrm{C}$, respectively.

Comparing with theory, companies did not report having any fear of the outcome of their actions in social networks, as suggested by Harris and Rae (2009). And they agree with Blanchard (2010), who states that their performances in social networks can make them more proactive as to the changing needs of customers.

Unlike suggested by the same author, however, actions by competition did not appear in interviews, seeming to be a distant concern from the performance of companies studied in their social networks.

\subsection{Relationship marketing}

Company A and Company B do not have a structured relationship marketing department which participates in creating action strategies for social networks. Marketing and public relations departments do, however, have these functions, as shown in Chart 5 .

Company $\mathrm{C}$ already has a relationship marketing department that manages the company's database and carries out actions according to the demand of the business units. This department does not have an interface with the operating strategies in social networks, that is, the nuclei do not use databases to publish actions on social networks, since the database does not have the address of the user profiles in social networks.

According to Chart 5, the three companies studied have the same goal in their actions, referring to the concepts of relationship marketing: generating relationships to become closer to users, seeking their preference at time of purchasing. This preference is intended to build a long-term relationship and build customer loyalty.

In Company $\mathrm{A}$ and Company $\mathrm{B}$, which do not have a structured marketing relationship departments, RM actions are performed by other departments. These areas and activities are included in Blanchard's presentation (2010), in the theoretical review item. 


\begin{tabular}{|c|c|c|c|}
\hline Elements & Company A & Company B & Company C \\
\hline $\begin{array}{l}\text { Relations with } \\
\text { relationship marketing }\end{array}$ & $\begin{array}{l}\text { - Does not have a specific } \\
\text { department, but actions } \\
\text { carried out in social } \\
\text { networks are relationship } \\
\text { marketing actions. }\end{array}$ & $\begin{array}{l}\text { - Does not have a specific } \\
\text { department, but actions } \\
\text { carried out in social } \\
\text { networks are relationship } \\
\text { marketing actions. }\end{array}$ & $\begin{array}{l}\text { - Has two RM departments, } \\
\text { but they do not have any } \\
\text { interface with actions carried } \\
\text { out in social networks. Their } \\
\text { actions may be considered } \\
\text { relationship management } \\
\text { actions. }\end{array}$ \\
\hline $\begin{array}{l}\text { Identified goals referring } \\
\text { to relationship marketing } \\
\text { concepts }\end{array}$ & $\begin{array}{l}\text { - To build a relationship with } \\
\text { their audience, to make it } \\
\text { loyal in the long-term. }\end{array}$ & $\begin{array}{l}\text { - To build a relationship } \\
\text { capable of generating } \\
\text { preference for the brand. }\end{array}$ & $\begin{array}{l}\text { - To build a relationship with } \\
\text { their audience, so that they } \\
\text { trust the brand and become } \\
\text { loyal to it. }\end{array}$ \\
\hline $\begin{array}{l}\text { Identified functions of } \\
\text { relationship marketing }\end{array}$ & $\begin{array}{l}\text { - Customer support } \\
\text { - Databank } \\
\text { - Communication with } \\
\text { customers. }\end{array}$ & $\begin{array}{l}\text { - Customer support } \\
\text { - Actions for employees. } \\
\text { - Communication with } \\
\text { customers. }\end{array}$ & $\begin{array}{l}\text { - Customer support } \\
\text { - Databank } \\
\text { - Communication with } \\
\text { customers. }\end{array}$ \\
\hline $\begin{array}{l}\text { Implementation of } \\
\text { RM concepts by the } \\
\text { IDIP model (Identify, } \\
\text { Differentiate, } \\
\text { Interact and Personalize) }\end{array}$ & $\begin{array}{l}\text { - Identifying audience } \\
\text { and network in which it is } \\
\text { present } \\
\text { - Separation of active and } \\
\text { committed users } \\
\text { - Interaction through Twitter } \\
\text { and Orkut } \\
\text { - There is no personalization } \\
\text { of actions in networks. }\end{array}$ & $\begin{array}{l}\text { - Audience is not identified } \\
\text { - There is no separation of } \\
\text { network users } \\
\text { - Interaction through } \\
\text { Twitter } \\
\text { - There is no personalization } \\
\text { of actions in networks. }\end{array}$ & $\begin{array}{l}\text { - Audience is not identified } \\
\text { - There is no separation of } \\
\text { network users } \\
\text { - Interaction through } \\
\text { Twitter, Orkut and Facebook } \\
\text { - There is no personalization } \\
\text { of actions in networks }\end{array}$ \\
\hline
\end{tabular}

CHART 5 - Comparative analysis of relationship marketing

Source: the authors.

Company A and Company C have similar functions in social networks: customer services, database and communication with customers. Company B already has customer services and communication with clients, and replaces the database function with marketing by employees.

Both Company B and Company C perform only one of the process steps proposed by Peppers and Rogers (1994) - interaction with the audience through mentioned networks.

These actions do not suffer any kind of segmentation: they are carried out alike for all users who are in the company's contact networks. Company A carries out a more structured process before performing its actions, since it undergoes a process to identify the target audience and to targeting users who are truly committed and active.

\section{FINAL CONSIDERATIONS}

This study aimed at exploring how companies use social networks to build customer relationships. To do so, it revisited theories about social networking and relationship marketing, in order to base analysis of case studies in the light of these concepts.

In theory, we can observe that, for a company to be active in a social network, it has to have already entered the Internet corporately through the creation of institutional sites.

According to Castells (1999), enrollment in social networks can be characterized as a moment in which a company ceases to have static and controlled content and progresses to an environment with user-generated content, over which the company has no control.

Based on comparative analysis of the three cases, we can answer the work's main objective, concluding that the studied companies are using social media as a channel to deliver content and services that contribute to building customer relationships.

Carrying out this type of action occurs through the establishment of a relationship with users, both directly and through influencers who have credibility to endorse contents that the brand wishes to convey, affording it visibility within 
social networks, defined by the number of users that can be impacted.

We observed that the three studied companies use Twitter - a social network that is on the rise. They all joined this network casually, without any concrete reasons for doing so, considering that several companies joined for an unknown reason. Currently, they carry out actions in the network because, apart from believing in the potential of this media, it offers a quick and simple user interaction.

Regarding Orkut, one can conclude that companies carry out their actions in order to reach their target audience found there. Therefore, this social network is used mainly for having a critical audience and because it is very popular in Brazil. Facebook is considered a new network in Brazil, with a more select audience. It is considered, however, that it is still in a development stage and that companies will soon adapt to it because of its distinctive features, such as the ability to develop applications.

The implementation of social networking strategies is usually the responsibility of a third party (agency), in charge of monitoring networks and disclosing contents. What we can observe, however, is that, in the case of Company C, there is an employee, graduated in journalism, who is responsible for this activity. This has to do with to the fact that it is a media company, whose employees are familiar with this activity and are trained to create contents and communicate with customers.

The support of top executives to actions in social networks is concrete in the three cases studied, but investments approved by them for this purpose are very small.

This is because there is lack of financial return metrics for this type of action. Therefore, top executives do not feel comfortable investing in something for which they do not know for sure what the returns will be.

Thus, a challenge for companies, agencies and scholars of this topic is the development of metrics capable of demonstrating the financial returns that actions in social networks bring to companies, proving that this result goes beyond the number of people impacted.
The use of networks was presented as a process that still being developed within all three companies, and it is possible to see that they are used more as a tool for relationship building, in which companies interact with users to answer their questions or provide other services, rather than as a channel for gathering information to be turned into marketing actions.

Users in networks are segmented, when the company so desires, in an attitudinal way, based on declared interests, such as communities to which they belong, blogs they read, twitters they follow, generating clusters of interest in social networks with which companies can try to interact.

The structures for implementing social networking in the cases studied vary in format and report levels. We perceived in this a relevant topic for the area of Marketing, and recommend carrying out studies that evaluate organizational structures related to Marketing that are being used to implement social networks.

For example, in two cases this structure is external and connected to a Public Relations/ Communications Agency. Do these third parties in fact have the best ability to carry out interactions in social networks on behalf of companies? Aren't companies missing an opportunity to build relationships with customers, using areas that have already developed this expertise, such as Customer Services, Database Marketing, all controlled more closely by Marketing?

This is an important consideration which takes us back to the 1990s, when Telemarketing Services were carried out by third parties. Once the Consumer Protection Code was created, this function was internalized and there was a great gain in terms of improved services and use of information obtained from these interactions by marketing departments, who have to monitor what consumers think and want in terms of services.

Managerially, a great opportunity for companies is to build a better interface for the management of social networking and marketing departments, so that actions performed in networks happen seamlessly, enabling the customization of actions proposed by Peppers and 
Rogers (1994). For this to be so, however, there needs to be an update or creation of database of customers and prospects of the company with information on the addresses of their profiles in the networks, on networks that they use the most, on how often and so on. Based on this information, it will be possible to develop custom actions for each profile over the networks, not only through direct mail or email marketing, which often are not read by recipients. For this to happen effectively, it is also necessary that there be a greater investment in skilled labor and technological resources, amongst others. That is, to invest in processes, structure and systems to create an intelligence within social networks.

It is noteworthy that this study has limitations that do not allow us to extrapolate the data obtained for the studied universe, due to its qualitative aspect and the limited number of companies studied.

As contributions, this study breaks new ground by exploring the use of social networks in large companies from different sectors, and presents some thought on the organizational structures used by these companies and the proximity of these actions with the Relationship Marketing function, extremely studied by scholars.

Based on the above, we conclude that social networks do represent an opportunity to improve the interaction with each company's target audiences, allowing them not only to know him better, but to also do so quickly. There is still, however, considerable scope for the personalization of this interaction, structuring and carrying out the functions of relationship marketing within social networks.

\section{REFERENCES}

BARDIN, L. Análise de conteúdo. 3. ed. Lisboa: Ediçôes 70, 2004.

BERRY, L. Relationship marketing. In: SHOSTAK, G. L. Emerging perspectives in services marketing. Chicago: AMA, 1983. p. 49-64.
BLANCHARD, O. A. Social media program planning \& ROI, 2010. Disponível em:<http:// www.slideshare.net/thebrandbuilder/buzz-2010presentation>. Acesso em: 26 mar. 2013.

BOYD, D. Friendster and publicly articulated social networks. In: CONFERENCE ON HUMAN FACTORS AND COMPUTING SYSTEMS, 2009, Vienna. [Annals...]. Vienna: ACM SIGCHI, 2009, p. 1279-1282.

; ELLISON, N. Social network sites: definition, history and scholarship. Journal of Computer-Mediated Communication. Chicago, v.13, n.1, p. 210-230, Oct. 2007.

CASTELLS, M. A sociedade em rede. 8. ed. São Paulo: Paz e Terra, 1999.

COMM, J. O poder do Twitter: estratégias para dominar seu mercado e atingir seus objetivos com um tweet por vez. São Paulo: Gente, 2009.

\section{DEGENNE, A.; FORSÉ, M. Introducing social} networks. London: Sage, 1999.

FACEBOOK. c2012. Disponível em: <www. facebook.com>. Acesso em: 12 nov. 2012.

FERREIRA, S.; SGANZERLLA, S. Conquistando o consumidor. São Paulo: Gente, 2000.

GRANOVETTER, M. The strenght of weak ties. The American Journal of Sociology. London, v. 78, n. 6, p. 1360-1380, 1973.

The strenth of weak ties: network theory revisited. Sociological Theory, Malden, v. 1, p 203- 233, 1983. Disponível em: <http://www. soc.ucsb.edu/faculty/friedkin/Syllabi/Soc148/ Granovetter\%201983.pdf >. Acesso em: 07 nov. 2012.

GUMMESSON, E. Marketing de relacionamento total. Porto Alegre: Bookman, 2005.

HARRIS, L.; RAE, A. Social network: the future of marketing for small business. Journal of 
Business Strategy, Bradford, v. 30, n. 5, p.24-31, Jan./Mar. 2009.

KURUCZ, V. Perspectives of viral marketing among managers: an internet based assessment. 2008. 103 f. Master's Thesis (Communication and Economics) - Faculties of Communication and Economics Science, University of Lugano, Lugano, 2008. Disponível em: < http://www.bul.unisi.ch/ cerca/bul/memorie/master/pdf/0708Kurucz.pdf> . Acesso em: 20 mar. 2013.

LEVITT, T. After the sale is over. Harvard Business Review, Boston, v. 61, n. 5, p. 87-93, Sep./Oct. 1983.

LINDGREEN, Adam. A framework for studying relationship marketing dyads. Qualitative Market Research, Bradford, v. 4, n. 2, p. 75-88, 2001.

MANGOLD, W. G.; FAULDS, D. J. Social media: the new hybrid element of the promotion mix. Business Horizons, Indiana, v. 52, n. 4, p. 357-365, July 2009.

MCKENNA, R. Marketing de relacionamento. Rio de Janeiro: Campus, 1993.

OLDENBURG, R. The great good place. New York: Marlowe and Co., 1999.

ORKUT. 2012. Disponível em: <http://www. orkut.com.br/Main\#MembersAl.>. Acesso em: 12 nov. 2012.

ORRICO, A. Negócios em 140 toques. Folha de São Paulo, São Paulo, 14 abr. 2010. Informática, p. F3.

PEPPERS, D.; ROGERS, M. Marketing um a um: marketing individualizado na era do cliente. Rio de Janeiro: Campus, 1994.

QUAN-HAASE, A. ; WELLMAN, B. How does the internet affect social capital. In: HUYSMAN, M.; WULF, V. (Org.) IT and social capital. New York: Elsevier, 2002. p. 38-58.
RECUERO, R. Redes sociais na internet. Porto Alegre: Sulina, 2009.

SHIH, C. The Facebook era: tapping online social networks to build better products, reach new audiences, and sell more stuff. New York: Prentice Hall, 2009.

SMITH, T. The social media revolution. International Journal of Marketing Research, Chicago, v. 51, n. 4, p. 559-561, 2009.

INDO.POST.COM BREAKING NEWS AND OPINION. Brazil surpassed India and now becoming the number two largest country connecting to Facebook social networking, while America remains the number one biggest country on Facebook. May 2012. Disponível em: <http://www.indopost.com/blog/2012/05/ brazil-surpassed-india-and-now-becoming-thenumber-two-largest-country-connecting-tofacebook-social.html>. Acesso em 18 set. 2012.

TECHCRUNCH. Analyst: Twitter passed 500m users in june 2012, 140m of them in US; Jakarta 'biggest tweeting' city. Disponível em: <http://techcrunch. com/2012/07/30/analyst-twitter-passed-500musers-in-june-2012-140m-of-them-in-us-jakartabiggest-tweeting-city/>. Acesso em: 11 nov. 2012.

TELLES, A. Orkut.com. São Paulo: Landscape, 2006.

VAVRA, T. G. Marketing de relacionamento: aftermarketing. São Paulo: Atlas, 1993.

WASSERMAN, S.; FAUST, K. Social network analysis: methods and applications. Cambridge: Cambridge University Press, 1994.

WATZLAWICK, P.; BEAVIN, J. H.; JACKSON, D. D. Pragmática da comunicaçáo humana. 11. ed. São Paulo: Cultrix, 2000.

YIN, R. K. Estudo de caso: planejamento e métodos. 3. ed. Porto Alegre: Bookman, 2005. 
APPENDIX A - TABLE REFERRING TO TOPICS AND BIBLIOGRAPHY

\begin{tabular}{|c|c|c|c|}
\hline & Topic & $\begin{array}{l}\text { Bibliographical } \\
\text { references }\end{array}$ & Questions \\
\hline \multicolumn{2}{|c|}{ The use of the internet by companies } & $\begin{array}{l}\text { - KOSIUR (1977) } \\
\text { - CASTELLS (1999) } \\
\text { - CASTELLS (2001) }\end{array}$ & $\begin{array}{l}\text { How long ago did the company create its institutional site/campaign? } \\
\text { How effective are campaigns in the site itself? } \\
\text { Do consumers interact with the company through the institutional site? } \\
\text { (For example: asking questions.) }\end{array}$ \\
\hline \multicolumn{2}{|c|}{ Social networks } & $\begin{array}{l}\text { - BOYD (2007) } \\
\text { - COMM (2009) } \\
\text { - RECUERO (2009) } \\
\text { - SHIH }(2009) \\
\text { - TELLES (2006) }\end{array}$ & $\begin{array}{l}\text { What are social networks, in your opinion? } \\
\text { What are social media, in your opinion? } \\
\text { Why did you decide to be a part of certain social networks? } \\
\text { What type of information are you looking for? } \\
\text { How is the information collected used in planning marketing initiatives? } \\
\text { What do you want to divulge? The brand, the products, their suggested } \\
\text { usage, or rendering of services? } \\
\text { Who monitors/carries out action within social media? (the Brand } \\
\text { Manager, the Communications Manager, the External Relations } \\
\text { Manager, Agencies). What is the role of each one of the staff involved } \\
\text { in the relationship/communications process through social networks? } \\
\text { What type of action do you carry out? Example. } \\
\text { Did you place your brand as a network user or did you use other users } \\
\text { as a channel for spreading information? } \\
\text { Do you use Twitter? Why? What criteria guided your choice? } \\
\text { Do you use Facebook? Why? What criteria guided your choice? } \\
\text { Do you use YouTube? Why? What criteria guided your choice? } \\
\text { How efficient do you think are the abovementioned networks? Which } \\
\text { do you consider brings the best results? } \\
\text { How often do you use these networks? What kind of information do } \\
\text { you use them most frequently for? } \\
\text { How is the clients' feedback dealt with by the company? } \\
\text { What is the opinion of the top executives about social networks - how } \\
\text { integrated are they with the company's communications strategies? } \\
\text { How do you see the future of these networks within the company and } \\
\text { the market in general? } \\
\text { If you had to state three determining factors for success within social } \\
\text { networks, what would they be? } \\
\text { What do you consider is your company's strong point within social networks? } \\
\text { What do you consider is your company's weak point within social networks? } \\
\text { What returns do social networks give your company? How is this } \\
\text { return measured? } \\
\text { Could you give us an example of successful use of social networks? }\end{array}$ \\
\hline \multirow[t]{11}{*}{$\begin{array}{l}\text { Relationship } \\
\text { marketing }\end{array}$} & $\begin{array}{l}\text { Relationship marketing and social } \\
\text { networks }\end{array}$ & \multirow{11}{*}{$\begin{array}{l}\text { - GUMMESSON (2005) } \\
\text { - GUMMESSON (2010) } \\
\text { - HUBERMAN (2008) } \\
\text { - ROCHA (2007) } \\
\text { - PEPPERS (1994) }\end{array}$} & \multirow{11}{*}{$\begin{array}{l}\text { Is there, in your company, any connection between social networks and } \\
\text { relationship marketing, or are they separate things? } \\
\text { Are social networks used to establish relationships between clients: } \\
\text { What is the company's goal concerning relationship marketing? Why } \\
\text { does it go through with it? } \\
\text { Considering that, to gain loyal clients, these must go through the stages } \\
\text { of obtaining, satisfying, keeping and expanding, at what stage do you } \\
\text { think your clients are at? } \\
\text { Who does relationship marketing happen with? With the supplier? } \\
\text { Client? What is the focus? } \\
\text { Where do you keep this information about clients? Is there a database? } \\
\text { How is this managed? } \\
\text { Is there any kind of routine for contacts with clients? } \\
\text { How does communication with these clients occur to establish trust } \\
\text { and commitment? } \\
\text { What do you consider a value offer for clients? } \\
\text { What do clients consider a value offer? } \\
\text { How do you identify clients' expectations? } \\
\text { How do you identify the difference between the quality offered and } \\
\text { the quality perceived? } \\
\text { Do you use and loyalty program with clients? What for? } \\
\text { Is there a loyalty program or are there special offers for main clients? } \\
\text { How do you separate target customers? } \\
\text { Which of the parties has the greatest power? Is there abuse of power } \\
\text { by any of the parties? } \\
\text { Is there a feeling of commitment between the parties? } \\
\text { Is your client predisposed to give up certain choices? To run certain risks? } \\
\text { Does your company adapt to the transformations in clients' demands? } \\
\text { How is the RM implementation process in your company? (IDIP: } \\
\text { identify, differentiate, interact, personalize) } \\
\text { Is there any relationship initiative for greater value clients (most } \\
\text { rentable)? } \\
\text { How are clients contacted? Through phone, e-mail, or another channel? } \\
\text { Is there interaction as a consumer through the internet? }\end{array}$} \\
\hline & Goals of relationship marketing & & \\
\hline & $\begin{array}{l}\text { Functions of relationship } \\
\text { marketing: interaction }\end{array}$ & & \\
\hline & $\begin{array}{l}\text { Functions of relationship } \\
\text { marketing: data bank }\end{array}$ & & \\
\hline & $\begin{array}{l}\text { Functions of relationship } \\
\text { marketing: communication with } \\
\text { clients }\end{array}$ & & \\
\hline & $\begin{array}{l}\text { Functions of relationship } \\
\text { marketing: services for clients }\end{array}$ & & \\
\hline & $\begin{array}{l}\text { Functions of relationship } \\
\text { marketing: differentiation }\end{array}$ & & \\
\hline & $\begin{array}{l}\text { Functions of relationship } \\
\text { marketing: actions for loyalty }\end{array}$ & & \\
\hline & $\begin{array}{l}\text { Relationship marketing } \\
\text { prerequisites }\end{array}$ & & \\
\hline & \begin{tabular}{|l|} 
Relationship marketing \\
implementation
\end{tabular} & & \\
\hline & E-relationship & & \\
\hline
\end{tabular}

Source: the authors. 